\title{
Unsatisfactory completeness of nurses' records in the medical records of users with tuberculosis
}

\author{
Completude insatisfatória dos registros de enfermeiros nos prontuários dos usuários com tuberculose \\ Completud insatisfactorio de los registros de enfermeros en los prontuarios de los usuarios con tuberculosis
}

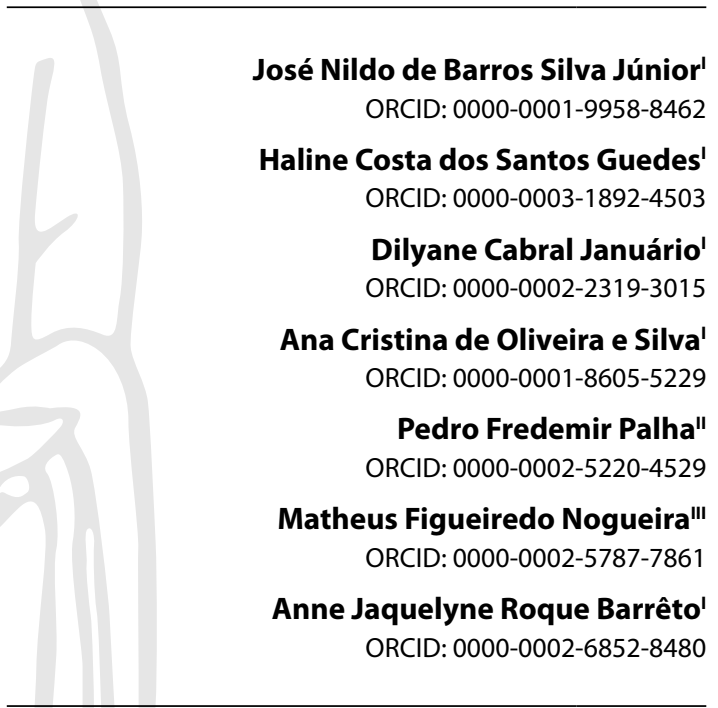

'Universidade Federal da Paraíba. João Pessoa, Paraíba, Brazil. "Universidade de São Paulo. Ribeirão Preto, São Paulo, Brazil. I"Universidade Federal de Campina Grande. Cuité, Paraíba,

Brazil.

How to cite this article: Silva Júnior JNB, Guedes HCS, Januário DC, Silva ACO,

Palha PF, Nogueira MF, et al. Unsatisfactory completeness of nurses' records in the medical records of users with tuberculosis. Rev Bras Enferm. 2022;75(3):e20210316. https://doi.org/10.1590/0034-7167-2021-0316

Corresponding author: José Nildo de Barros Silva Júnior E-mail: nildoenfer@hotmail.com

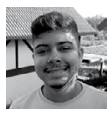

EDITOR IN CHIEF: Álvaro Sousa ASSOCIATE EDITOR: Ana Fátima Fernandes

Submission: 05-28-2021

Approval: 08-26-2021

\section{ABSTRACT}

Objectives: to evaluate the completeness of nurses'records on the execution of the nursing process in assistance of tuberculosis patients at Primary Care. Methods: this was a retrospective documental study, with 190 records in Family Health Units of a city in the state of Paraíba. The data were analyzed according to descriptive statistics, Pareto Diagram, and trend analysis. Results: the overall mean incompleteness of records was $53.01 \%(D P=26.13)$. Therefore, the results presented very poor completeness classification related to nursing diagnosis (88.9\%), nursing assessment $(66.8 \%)$, data collection $(60.5 \%)$, while nursing interventions were classified as regular (11.1\%). The nursing diagnosis was the only variable with a decreasing trend of non-completeness. Conclusions: incompleteness of nurses' records in the medical records of users with tuberculosis. Evaluation strategies, permanent and continuing education are indispensable in the quality of nurses' documentation, directly implying the Systematization of Quality in Nursing Care.

Descriptors: Nursing; Nursing Process; Nursing Records; Tuberculosis; Primary Health Care.

\section{RESUMO}

Objetivos: avaliar a completude dos registros de enfermeiros acerca da execução do processo de enfermagem no cuidado às pessoas com tuberculose na Atenção Primária. Métodos: estudo documental, retrospectivo, com 190 prontuários em Unidades de Saúde da Família de uma cidade no estado da Paraíba. Os dados foram analisados segundo estatística descritiva, Diagrama de Pareto e análise de tendência. Resultados: a média geral de incompletude dos registros foi de $53,01 \%$ ( $D P=26,13)$. Classificação de completude muito ruim relativa ao diagnóstico de enfermagem (88,9\%), avaliação de enfermagem (66,8\%), levantamento de dados $(60,5 \%)$, enquanto as intervenções de enfermagem se classificaram como regular $(11,1 \%)$. O diagnóstico de enfermagem foi a única variável com tendência de não completude decrescente. Conclusões: incompletude dos registros de enfermeiros nos prontuários dos usuários com tuberculose. Estratégias de avaliação, educação permanente e continuada são indispensáveis na qualidade da documentação dos enfermeiros, implicando diretamente a Sistematização da Assistência de Enfermagem de qualidade.

Descritores: Enfermagem; Processo de Enfermagem; Registros de Enfermagem; Tuberculose; Atenção Primária à Saúde.

\section{RESUMEN}

Objetivos: evaluar completud de registros de enfermeros sobre la ejecución del proceso de enfermería en el cuidado a personas con tuberculosis en la Atención Primaria. Métodos: estudio documental, retrospectivo, con 190 prontuarios en Unidades de Salud de la Familia de una ciudad del estado de Paraíba. Datos analizados segundo estadística descriptiva, Diagrama de Pareto y análisis de tendencia. Resultados: mediana general de incompletud de registros fue de $53,01 \%(\mathrm{DP}=26,13)$. Clasificación de completud muy mala relativa al diagnóstico de enfermería $(88,9 \%)$, evaluación de enfermería $(66,8 \%)$, levantamiento de datos $(60,5 \%)$, mientras intervenciones de enfermería se clasificaron como regular (11,1\%). Diagnóstico de enfermería fue la única variable con tendencia de no completud decreciente. Conclusiones: Incompletud de registros de enfermeros en los prontuarios de usuarios con tuberculosis. Estrategias de evaluación, educación permanente y continuada son indispensables en la calidad de documentación de los enfermeros, implicando directamente la Sistematización de Asistencia de Enfermería de calidad.

Descriptores: Enfermería; Proceso de Enfermería; Registros de Enfermería; Tuberculosis; Atención Primaria de Salud. 


\section{INTRODUCTION}

In the development of healthcare products, the clinical documentation of patient care through the medical record is a source of information inherent to the assistance and management of health actions, whose clinical and administrative characteristics assist in decision making. Moreover, the medical record is an essential instrument of shared communication between health professionals, ensuring the continuity and completeness of care. Thus, the quality of clinical documentation has been the subject of public policies, guidelines, and standards of health services to optimize the work organization ${ }^{(1)}$.

In this context, we report to the nursing process (NP), an important technological tool for recording the activities of the nursing team. In Brazil, since 2002, the documentation of the NP became mandatory in all public and private health services, being regulated by Resolution № 358/2009 of the Conselho Federal de Enfermagem (Federal Council of Nursing) (Cofen) $)^{(2)}$. Its article 6, concerning the formal record of the NP execution, mentions the need to present a summary of the data collected on the patient's health-disease process; the nursing diagnoses (ND) based on the data obtained, critical and clinical judgment; the nursing actions or interventions; besides the evaluation of the results achieved by the nursing actions implemented ${ }^{(3)}$.

The nursing process is a methodological model that guides nurses' professional care and collaborates to document nursing practice. Its purpose is to recognize health-disease situations to facilitate the nurse's clinical, therapeutic, and scientific reasoning process for problem-solving, favoring critical thinking for nursing interventions in a holistic and quality way for the individual, family, and community. This methodology provides nurses' autonomy within their practice space and stimulates more professional recognition and healthcare quality ${ }^{(4)}$. Moreover, Cofen Resolution 429/2012 reinforces the importance and obligation of those records $s^{(5)}$.

Thus, health services have been mobilizing to meet this requirement, including primary health care (PHC) services. At the PHC, it faces difficulties in implementing NP because of nurses' resistance, along with political and administrative conceptions that create barriers to encourage professional qualification, not valuing its practical implementation, in addition to erroneous comprehension of the NP implementation, with a discrepancy between the recommendation and what was observed in practice(6).

The nurses' role in the Family Health Strategy (FHS) has been gaining prominence in the commitment to activities and practices of education, health promotion, and disease prevention ${ }^{(7-8)}$. As an example, is cited its performance in the operationalization of the Tuberculosis Control Program, through managerial activity related to planning, organization, service evaluation, and implementation of actions like identifying respiratory symptoms, conducting nursing consultations, notifying confirmed cases, requesting tests, among other activities, collaborating to articulate beside other PHC professionals to reduce weaknesses that permeate the tuberculosis care(TB) $)^{(9)}$.

So, TB is a serious but curable public health problem worldwide. About 10 million new cases occurred in 2019, with 1.2 million deaths. In 2020, the country registered 66,819 new TB cases, with an incidence of 31.6 cases per 100,000 inhabitants. Brazilian Northeast was the second region with the highest-ranking number of TB notifications, with 17,287 cases, 999 only in the state of Paraíba ${ }^{(10)}$.

That is an alarming scenario and requires implementing specific strategies to achieve the goals proposed by the World Health Organization (WHO) to eradicate the disease. In this sense, the PHC nurse's record becomes essential to monitoring, planning, and evaluating the disease, providing subsidies to assess the ability of municipalities to perform actions in the management of $\mathrm{TB}^{(11-12)}$.

In this scenario, the nurse's register in the medical record is translated as indispensable in the NP, promoting the identification of significant and fundamental information to be monitored to ensure that the nursing team reaches crucial data for safe assistance with legal support. That way, during TB patient's consultation and monitoring, the NP record must be complete, with quality, consistency, reliability, and clarity. Thus, this data set will support the appropriate decision-making, guarantee continuity of care and the maintenance of ethical and legal aspects, and contribute to achieving the goals proposed by WHO to eradicate the disease ${ }^{(13-14)}$.

A bibliographic survey conducted in the Scientific Electronic Library Online (SciELO), Latin American and Caribbean Literature on Health Sciences (LILACS), PubMed, Web of Science, and Scopus databases, published between 2016 and 2021, identified publications on the evaluation of documentation in TB care at PHC with numerous healthcare professionals, including nurses, using computerized systems $\mathrm{s}^{(15-16)}$, and on the completeness of physical ${ }^{(17)}$ and computerized ${ }^{(18)}$ medical records, but did not include the NP. It was identified a study that evaluated elements of the NP in nursing consultations with TB patients at PHC through a direct interview with nurses ${ }^{(13)}$. However, there is no information about the completeness and trend of non-completeness of the NP record in this context, nationally or internationally. That highlights the importance of this study since it is a subject of relevance to public health.

This research starts from the following guiding question: How is the completeness of records on the execution of the nursing process in $\mathrm{TB}$ care at $\mathrm{PHC}$ ?

\section{OBJECTIVES}

To evaluate the completeness of nurses' records on the execution of the nursing process in assistance of tuberculosis patients at Primary Care.

\section{METHODS}

\section{Ethical aspects}

The Comitê de Ética em Pesquisa do Centro de Ciências da Saúde da Universidade Federal da Paraíba (Research Ethics Committee from the Health Sciences Center of the Federal University of Paraíba) approved the project, following the recommendations of Resolution 466/2012 of the Conselho Nacional de Saúde (National Health Council). 


\section{Design, period, and place of study}

This research is a documental and retrospective study, guided by the Strengthening the Reporting of Observational Studies in Epidemiology (STROBE), developed at the Family Health Units (FHUs) in a city at the Eastern State of Paraíba. The city is considered a priority by the Ministry of Health (MH) in TB control actions, with a healthcare model organization employing a territorial demarcation by five Sanitary Districts (SD), which are characterized in this study by the acronyms SD-A, SD-B, SD-C, SD-D, and SD-E, to ensure the privacy of the Family Health Teams (FH Teams). Data collection was conducted between July and September 2020, in morning and afternoon shifts, in places that safeguarded the confidentiality of information.

\section{Population or sample; criteria of inclusion and exclusion}

The studied population was composed of nurse records treating TB patients who have been in followed-up at the FHU of the municipality that met some inclusion criteria. Records of TB users residing in the municipality studied and completed the followup during treatment of the Programa de Controle da Tuberculose (PCT) [Tuberculosis Control Program (TCP)] (individuals over 18 years of age). However, records about to be closed were excluded due to a change of diagnosis or transfer to another municipality.

For the sample calculation, we considered the survey of new cases of the disease registered by PHC services that started and finished treatment between January 2015 and December 2019, establishing 1,191 records divided into the five SD (255 related to $S D A ; 410$, to $B ; 224$, to $C ; 214$, to $D ;$ and 88 , to E). The following parameters were accepted: $P$ (Proportion of occurrence of the event [incompleteness of records] in the population) $=10.5 \%$, as found in the study by Nielsen and Silva ${ }^{(19)} ; \mathrm{Cl}$ (Confidence Index) $=95 \%$; and sample error of $4 \%$. The result was a sample of 190 medical records, calculated using the software $\mathrm{R}$, version 4.0.3.

For the selection process of the medical records, it was initially carried out a proportional sampling, considering the same incompleteness rate for the five DSs and the equal proportion of TB patients ( 41 records in SD A; 65 in B; 36 in C; 34 in D; and 14 in E). Afterward, using systematic probability sampling, an ordered list of all records was drawn up, in which the population quantity was divided by the sample to obtain the systematization factor $(\mathrm{k}$ $=\mathrm{N} / \mathrm{n})$, resulting in the systematization factor $k=6(\mathrm{k}=1191 / 190$ $=6.27 \approx 6$ ). In order to ensure the sample randomness, it was chosen the first sample element (a) between 1 and $k$, that is, $1<a \leq k$, considering at random $a=3$. Next, the systematization line was completed based on this element until the sample size was complete.

\section{Study protocol}

The study used a structured form, based on the Manual de Recomendações para o Controle da Tuberculose (Manual of Recommendations for Tuberculosis Control)(20), in the Protocolo de Enfermagem no Tratamento Diretamente Observado (TOD) (Nursing Protocol for Directly Observed Treatment-DOT) of tuberculosis at Primary $\mathrm{Care}^{(21)}$, and on institutional documents that regulate nursing records at PHC. The form suffered readjustments and feasibility verification according to the research objectives through pilot testing. In this phase, $10 \%{ }^{(22)}$ of the sample was analyzed, i.e., 19 medical records selected by draw and favored reflection about some issues to refining some variables, and included in the final sample.

This study listed sociodemographic and clinical variables (age, gender, clinical form of TB) in addition to NP-related variables: data collection (methods used by the nurse for data collection, such as interview, physical examination, request for exams, and diagnostic tests, taking into account the clinical, epidemiological and psychosocial aspects); ND (interpretations of complaints and findings at the initial assessment, physical examination, and active problem); nursing interventions (planning to provide care, defining criteria to be used in prioritizing actions, user's preferences, basic human needs, and therapeutic plan); and nursing assessment (systematized comparison of the proposed goals with the results obtained to determine the effectiveness of the assistance provided).

\section{Analysis of results and statistics}

Data were coded in Microsoft Office Excel' 2019 spreadsheet, double-typed, and analyzed with $\mathrm{R}$ software, version 4.0.3, free and open to all. At first, it was performed the simple frequency and percentage of the variables. The trend equations of incompleteness weighted the variables in the time range from 2015 to 2019 , through the simple linear regression, where $y$ is the percentage of incompleteness, $x$ is the time variable (year), a and $\beta$ are the unknown parameters to be determined, while $\varepsilon$ is the unknown random error.

The significant variables are those with a $p$-value less than $5 \%$. The variable with the $\beta$ positive estimate increased while the other with the estimate $\beta$ negative decreased. In addition, the Pareto Diagram was used, consisting of a bar graph that systematizes the frequencies of occurrences from the highest to the lowest, allowing the identification of priority points for intervention in a curve of accumulated percentages ${ }^{(23)}$.

As a reference for the analysis of completeness, it was admitted the classification employed by Romero and Cunha ${ }^{(24)}$, with the following evaluation degrees: excellent (incompleteness $<5 \%$ ), good $(5 \% \leq$ incompleteness $<10 \%)$, regular $(10 \% \leq$ incompleteness $<20 \%$ ), poor $(20 \% \leq$ incompleteness $<50 \%)$, and very poor (incompleteness $\geq 50 \%$ ).

\section{RESULTS}

The research sample consisted of 190 medical records of patients diagnosed with $\mathrm{TB}$, followed by the family healthcare strategy. The patients had a mean age of 39.92 years $(S D=15.84)$, were mostly male $(n=122 ; 64.21 \%)$ and had a clinical form of pulmonary TB ( $n=167 ; 87.89 \%)$. Regarding the study's main objective, we observed a general average of incompleteness in records of $53.01 \%$ ( $D P=26.13)$. About classification of completeness in NP execution records, the variables Data collection, ND, and Nursing assessment were classified as very poor, while the Nursing intervention variable was classified as regular (Table 1). 
Table 1 - Distribution and classification of completeness in nursing process execution records of care for tuberculosis patients at primary health care, João Pessoa, Paraíba, Brazil, 2015-2019

\begin{tabular}{lccccccc}
\hline Variables & $\mathbf{2 0 1 5}$ & $\mathbf{2 0 1 6}$ & $\mathbf{2 0 1 7}$ & $\mathbf{2 0 1 8}$ & $\mathbf{2 0 1 9}$ & $\begin{array}{c}\text { Total } \\
\mathbf{n ( \% )}\end{array}$ & $\begin{array}{c}\text { Completeness } \\
\text { Classification* }\end{array}$ \\
\hline nata Collection & $7(58.3)$ & $10(58.8)$ & $20(62.5)$ & $33(58.9)$ & $45(61.6)$ & $115(60.5)$ & Very Poor \\
Nursing Diagnoses & $11(91.7)$ & $16(94.1)$ & $29(90.6)$ & $51(91.1)$ & $62(84.9)$ & $169(88.9)$ & Very Poor \\
Nursing Interventions & - & - & $4(12.5)$ & $4(7.1)$ & $13(17.8)$ & $21(11.1)$ & Regular \\
Nursing Assessment & $6(50.0)$ & $12(70.6)$ & $20(62.5)$ & $46(82.1)$ & $43(58.9)$ & $127(66.8)$ & Very Poor \\
\hline
\end{tabular}

$n$-number of records with incomplete filling out* ${ }^{*}$ The completeness classification is measured based on the number of records with incomplete fills $s^{(20)}$.

In the analysis of non-compliance through the Pareto Diagram, the absence of records related to ND was the biggest problem in the execution of the NP, representing $39.1 \%$ of the general noncompliance in nurses' records. Nursing assessment and data collection were NP stages that presented the slightest problem in the NP execution, with cumulative percentages of $68.5 \%$ and $95.1 \%$, respectively, related to the non-completeness of the registers. However, the variable Nursing interventions were responsible for only $4.9 \%$ of non-completeness in nurses' records. (Figure 1).

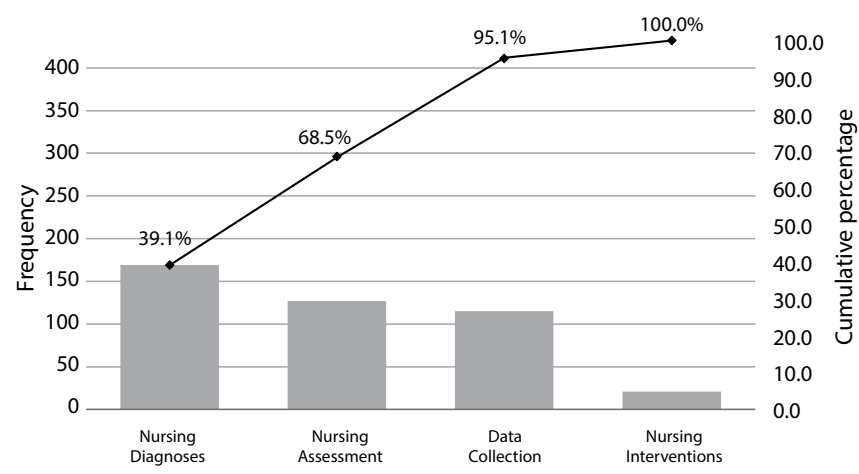

Figure 1 - Pareto diagram of non-completion of nursing process execution record in tuberculosis care at primary health care, João Pessoa, Paraíba, Brasil, 2015-2019

Table 2 presents the non-completeness trend models, and their main components for the variables analyzed. The steps Data Collection, Nursing Interventions, and Nursing Assessment were classified with an increasing trend of non-completeness, while the ND stage showed a decreasing trend.

Table 2 - Tendency of non-completeness of registers in nursing process execution of tuberculosis care at primary health care, João Pessoa, Paraíba, Brasil, 2015-2019

\begin{tabular}{lcccc}
\hline Variables & Model & $\mathbf{R}^{2}$ & $\boldsymbol{p}$ value & Trend \\
\hline Data Collection & $y=-1291,37+0,67 x$ & 0,3129 & 0,3270 & Increasing \\
Nursing Diagnoses & $y=3438,70-1,66 x$ & 0,5974 & 0,1250 & Decreasing \\
Nursing Interventions & $y=-8305,11+4,27 x$ & 0,7480 & 0,0584 & Increasing \\
Nursing Assessment & $y=-5844,99+2,93 x$ & 0,1450 & 0,5270 & Increasing \\
\hline
\end{tabular}

\section{DISCUSSION}

In Brazil, NP documentation is a formal requirement, developed in all areas where users' nursing care occurs. This formality has the perspective of enhancing the quality of the nurse's care and nursing assistance ${ }^{(25)}$.

We identified, in our findings, that the variable Data collection presented very poor completeness classification, with a tendency of increasing non-completeness in the medical record over the years. This result is worrisome since this stage allows nurses to apply various methods, such as interviews, physical examination, laboratory results, and diagnostic tests, considering clinical, epidemiological, and psychosocial aspects. While dealing with TB patients, there should be more attention in conducting thorough data collection since it will serve as a source of information that will subsidize the ND. Therefore, it must emphasize the need to register these data with quality and reliability to reflect the user's actual situation ${ }^{(21)}$.

In a research conducted with nurses on the analysis of records of the patient with tuberculosis, they observed that the reports about nursing history were limited to patients' vital signs and symptoms; this way, when being neglected, the other elements included in this investigation, related to the anamnesis and the physical examination, harms the integrality of the care ${ }^{(13)}$. Moreover, such a situation can be understood through the historicity of the biomedical model that, in turn, drives the non-reporting in medical records about the set of social determinants of health, since it overvalues the physical and biological aspects, fragmenting the assistance and distancing the TB user from comprehensive healthcare at the $\mathrm{PHC}$.

This weakness in the NP records provides barriers to the appropriate approach to the problems faced by users and the evaluation of the repercussions of the interventions prescribed and performed, besides suppressing possible diagnoses, changes in prescriptions, and nursing evolution. The completeness of the data collection is paramount because through these annotations are identified the observations of the changes that require more attention and support of nurses for the other phases of the NP. However, this step needs a scientific basis and calls for actions to support and strengthen the implementation of nurses' continuing education ${ }^{(3,16)}$.

In the present study, ND accounted for most of the overall non-compliance of records. However, their trend of non-completeness has been gradually decreasing. That can be translated due to a better understanding of the ND importance for nurses' practice since this professional's private activity promotes autonomy and assists in qualified and individualized support ${ }^{(26)}$.

The ND is delimited after obtaining and adequately recording the data collected through the nurse's clinical judgment process. The $\mathrm{MOH} / \mathrm{MS}$ recommends that this stage should be based on the ND classification by the North American Nursing Diagnosis Association NANDA, which has proven to be a crucial clinical utility device. It is worth mentioning that, in addition to NANDA, we have another tool known as Classificação Internacional das Práticas de Enfermagem em Saúde Coletiva (CIPESC) [International Classification of Nursing Practices in Collective Health], which plays a vital role concerning ND in the scope of the $\mathrm{PHC}^{(27-28)}$.

Research ${ }^{(29)}$ points out that $\mathrm{PHC}$ nurses recognized the importance of records of TB users. However, the study data characterized 
weaknesses in the records since a low predominance of annotations in the medical records was observed. That points to a lack of information about the users' particularities, making it impossible to detail this population better and ascertain characteristics that anticipate ND. Furthermore, verbalization at team meetings replaced consultations in medical records.

Another study ${ }^{(13)}$ developed at PHC in a city of Brazilian Northeast also drew our attention since it showed a higher percentage of respondents who traced the ND without the support of NANDA taxonomy and identified incompleteness regarding the ND record in the users' medical records. Furthermore, the study data showed that $\mathrm{PHC}$ nurses, for the most part, did not prescribe ND for users with TB, nor did they plan actions based on the ND; they performed their nursing prescriptions aiming only at the pathology, without considering the determinants linked to the social aspects in which the user was inserted.

That said, some weaknesses happen in the nurses' training and qualification processes about the NP record, in which they tend to reproduce the hegemonic care model, linked to the biomedical ideology, which collides with the implementation of the NP. Thus, given the analyses presented, there is a need to reflect on/intervene in nurses' practice to strengthen a holistic view of the patient, taking into account nursing praxis through the methodological organizational device that classifies ND to provide an opportunity for a standard language to implement nursing care $^{(13)}$.

Another finding of our study is linked to the variable Nursing Intervention, which showed a lower rate of overall non-completeness. This finding converges with the literature ${ }^{(25)}$ regarding the fact that the records of this information have a higher frequency in the patient's record than other NP steps. However, nursing interventions showed an increasing temporal trend towards noncompleteness in the records of PHC nurses regarding TB.

After prescribing the actions of the care plan, the implementation stage becomes tangible, applying the outlined prescriptions according to the client. As implementation of the interventions occurs, the nurse can reassess the TB patient, rewrite purposes, and modify the care plan as needed ${ }^{(30)}$.

In contrast to our study, research developed in the Brazilian South Region shows that the therapeutic plan's record presents itself in a fragmented way. That affects the users' assistance since it hinders the appreciation of the guided practices and, so, inserts them in situations that allow vulnerabilities in their treatment, which may end in the abandonment of treatment ${ }^{(31)}$.

Therefore, this can be explained by the results of a study ${ }^{(17)}$ that also points out the weaknesses related to the omission of nurses' reports regarding the interventions performed in TB medical records at PHC. It was observed that the annotations in the records were timid, especially those referring to the transmission of orientations to TB users, to the point that there were situations in which the orientations recorded in the records were potentially nonspecific. The notes' incompleteness caused by the nurse's non-recording becomes lost information, and the absence of documentation implies fragmentation and fragility in the quality of nursing actions.

Another aspect to recognize and draws our attention to the quality of nursing records is their legal support when it comes to implementing care in the face of the need for assistance in legal proceedings. Such peculiarity lies in the written testimony of health professionals in the legal defense of nurses involved in assistance since it serves as proof of the execution of the work activity, considering the alignment of practice with the consummation of registrations in medical records ${ }^{(32)}$.

After implementing the care plan, there is the need to perform the last phase of the NP execution, the assessment, to systematically compare the results obtained with the proposed goals, needing to be described in the medical record ${ }^{(3)}$. However, the findings reveal that the nursing assessment did not obtain a good completeness rating.

The evaluation of nursing assistance proposes investigating the monitoring of the patient's responses to the implemented care, enabling the detection of interventions that should be preserved, those that should be changed, and those that can be completed. Thus, it helps to evaluate the effectiveness of care, denoting contributions that their actions brought to the results achieved by the patients, favoring the understanding of the magnitude of this information to be documented ${ }^{(33)}$.

After considering the evidence found in our study about the recording of these pieces of information, it could be inferred that the care production for people with TB occurs without defining the ND. Factors show disregard toward the individuality of the patient and integrality of care. Thus, the process of clinical judgment for diagnostic reasoning is compromised, opposing the foundations of the NP, which has a holistic focus, centered on specific interventions with the patient and not only to the disease.

Therefore, physical records, a significant reality in the Brazilian health system, are seen as a document of legal value and an indicator of the quality of continuing care. Disregarding its documentation, besides being a disservice to society, constitutes a severe fault. We highlight a necessity and global trend for personal training and awarenessraising initiatives, aiming to sensitization of the NPs importance in the nurse's record when managing TB at PHC. The implementation of electronic patient records can also be recognized as a strategy capable of grouping information more accurately, contributing to better rates of completeness of the information.

\section{Study limitations}

Among the study's limitations, we highlighted the disposition of the medical records in the Basic Health Unit (UBS) since, in some places, there was no logical order or even no records at all, especially in the older files. The illegible handwriting in some records may have overestimated the number of incomplete records. Moreover, obtaining data based on medical records deprived us of a narrative construction about the subject since this medium does not provide a deepening level achieved in an in-person approach. However, these limitations did not compromise the development of this research, which can support the strengthening of policies aimed at the quality of NP documentation in the management of TB at PHC.

\section{Contributions to the fields of Nursing, Health or Public Policy}

Our results meet the interests of public health by elaborating fundamental data on NP records in TB management, conceiving 
it as an essential practice for decision making. The support of the argumentative reasoning emphasizes the lack of recognition by nurses of the importance of thoroughly filling the nursing records; it is necessary to value behavioral habits that involve the completeness of the records, which reflects on the integrality of care within the assistance praxis. It is recommended to consider the plurality of factors involved in registering the performance of nursing care, seeking a barrier-free that involve the assistance of those professionals so that they can systematize, guide, optimize medical judgment, the diagnostic reasoning, and the elaboration of the assistance plan with the scientific basis necessary to strengthen the nurse's care.

\section{CONCLUSIONS}

We identified unsatisfactory completeness of the nursing process documentation in the medical record regarding tuberculosis at the Primary Health Care. The nursing process should be implemented to establish and achieve purposes for disease control; however, the frailties identified in the records indicate the non-execution of this process, resulting in the fragmentation of care. By detecting these record's shortcomings, it is clear how much the nurse's care is still surrounded by a paradigm that urgently needs to be overcome.

We highlight the need for further studies to evaluate the development of the nursing register process with other populations, considering it as indispensable in nursing practice and ensuring it as a right and duty of the nursing service. Evaluation strategies like permanent and continuing education are indispensable in the nurses' documentation quality, directly implying the Systematization of Quality Nursing Care.

Our findings should be considered in clinical decision-making in the arena of public health since if these vulnerabilities are not considered in this scenario, they may hinder the response to tuberculosis control.

\section{FUNDING}

The authors would like to thank the Coordination for the Improvement of Higher Education Personnel (CAPES) for granting a master's degree scholarship to José Nildo de Barros Silva Júnior to carry out the study which originated this article.

\section{REFERENCES}

1. Ferreira LL, Chiavone FBT, Bezerril MS, Alves KYA, Salvador PTCO, Santos VEP. Analysis of records by nursing technicians and nurses in medical records. Rev Bras Enferm. 2020;73(2):e20180542. https://doi.org/10.1590/0034-7167-2018-0542

2. Conselho Federal de Enfermagem(COFEN). Resolução COFEN No 358/2009. Brasília-DF [Internet]. 2009 [cited 2020 Nov 5]. Available from: http://www.cofen.gov.br/resoluo-cofen-3582009_4384.html

3. Azevedo OA, Guedes ES, Araújo SAN, Maia MM, Cruz DALM. Documentation of the nursing process in public health institutions. Rev Esc Enferm USP. 2019;53:e03471. https://doi.org/10.1590/S1980-220X2018003703471

4. Lofti M, Zamanzadeh V, Valizadeh L, khajehgoodari M, Rezaei ME, Khalilzad MA. The implementation of the nursing process in lower-income countries: an integrative review. Nurs Open. 2020;7(1):42-57. https://doi.org/10.1002/nop2.410

5. Conselho Federal de Enfermagem (COFEN). Resolução COFEN № 429/2012. Brasília-DF, 30 maio 2012 [Internet]. 2012 [cited 2020 Dec 6]. Available from: http://www.cofen.gov.br/resoluo-cofen-n-4292012_9263.html

6. Ribeiro GC, Padoveze MC. Nursing Care Systematization in a basic health unit: perception of the nursing team. Rev Esc Enferm USP. 2018;52:e03375. https://doi.org/10.1590/S1980-220X2017028803375

7. Becker RM, Heidemann ITSB, Meirelles BHS, Costa MFBNA, Antonini FO, Durand MK. Nursing care practices for people with Chronic Noncommunicable Diseases. Rev Bras Enferm. 2018;71(Suppl 6):2643-9. https://doi.org/10.1590/0034-7167-2017-0799

8. Rodríguez AMMM, Mishima SM, Lettiere-Viana A, Matumoto S, Fortuna CM, Santos DS. Nurses' work at Family Health Strategy: possibilities to operate health needs. Rev Bras Enferm. 2020;73(Suppl 6):e20190704. https://doi.org/10.1590/0034-7167-2019-0704

9. Temoteo RCA, Carvalho JBL, Lira ALBC, Lima MA, Sousa YG. Nursing in adherence to treatment of tuberculosis and health technologies in the context of primary care. Esc Anna Nery Rev Enferm. 2019;23(3). https://doi.org/10.1590/2177-9465-ean-2018-0321

10. World Health Organization (WHO). Global tuberculosis report 2020: executive summary [Internet]. 2020 [cited 2021 Jan 10]; Available from: https://www.who.int/publications/i/item/9789240013131

11. Lima SVMA, Cruz LZ, Araújo DC, Santos AD, Queiroz AAFLN, Araújo KCGM, et al. Quality of tuberculosis information systems after record linkage. Rev Bras Enferm. 2020;73(Suppl 5):e20200536. https://doi.org/10.1590/0034-7167-2020-0536

12. Rabelo JVC, Navarro PD, Carvalho WS, Almeida IN, Oliveira CSF, JPA Haddad, et al. Performance assessment of primary healthcare services in tuberculosis control in a city in Southeast Brazil. Cad Saúde Pública. 2021;37:00112020. https://doi.org/10.1590/0102-311X00112020

13. Oliveira DRC, Enders BC, Vieira CENK, Mariz LS. Assessment of nursing consultations for tuberculosis patients at primary health care. Rev Eletrônica Enferm. 2016;18:e1153. https://doi.org/10.5216/ree.v18.32593

14. Maia DA, Valente GSC. The management of information on basic health care and the quality of Nursing Records. Investig Enferm [Internet]. 2018 [cited 2021 Feb 5];20(2). Available from: https://pesquisa.bvsalud.org/portal/resource/pt/biblio-995111

15. Tomberg JO, Gonzales RIC, Spagnolo LDML, Vieira DA, Harter J, Herrera JRRV. Use of electronic registration in tuberculosis detection: potentials and difficulties according to professionals. Cogitare Enferm. 2018; 23(3):e53918. https://doi.org/10.5380/ce.v23i3.53918 
16. Tomberg JO, Spagnolo LMDL, Valerão NB, Martins MDDR, Gonzales RIC. Records in tuberculosis detection: perception of health professionals. Esc Anna Nery. 2019;23(3):e20190008. https://doi.org/10.1590/2177-9465-ean-2019-0008

17. Silva Jr D, Silva Y, Nascimento E. Follow-up of users with tuberculosis: analysis of the quality of records in medical records. Rev Contexto Saúde. 2017;17(32):15-24. https://doi.org/10.21527/2176-7114.2017.32.15-24

18. Orfão NH, Crepaldi NY, Brunello MEF, Andrade RLDP, Monroe AA, Ruffino-Netto A, et al. Coordinated care for tuberculosis: data registration and implementation of a computerized system. Ciênc Saúde Coletiva. 2017;22:1969-77. https://doi. org/10.1590/1413-81232017226.15352016

19. Nielsen MBP, Silva AR. The importance of information recording in tuberculosis control. Salus J Health Sci [Internet]. 2015 [cited 2021 Mar 17];1(1):61-8. Available from: http://www.salusjournal.org/wp-content/uploads/2015/12/Salus.pdf

20. Ministério da Saúde (BR). Secretaria de Vigilância em Saúde. Departamento de Vigilância das doenças transmissíveis. Manual de recomendações para o controle da tuberculose no Brasil. 2 ed. Brasília: Ministério da Saúde [Internet]. 2019 [cited 2021 Apr 19]. Available from: https://www.saude.mg.gov.br/images/documentos/manual_recomendacoes_tb_2ed_atualizada_8maio19.pdf

21. Ministério da Saúde (BR). Secretaria de Vigilância em Saúde. Departamento de Vigilância Epidemiológica. Tratamento Diretamente Observado (TDO) da tuberculose na atenção básica: protocolo de enfermagem. Brasília: Ministério da Saúde [Internet]. 2011 [cited 2021 Apr 21];1(1):61-8. Available from: http://bvsms.saude.gov.br/bvs/publicacoes/tratamento_diretamente_observado_tuberculose.pdf

22. Bailer C, Tomitch LMB, D'ely RCSF. O planejamento como processo dinâmico: a importância do estudo piloto para uma pesquisa experimental em linguística aplicada. Rev Intercâmbio [Internet]. 2011 [cited 2021 Apr 22];129-14. Available from: https://revistas.pucsp.br/ index.php/intercambio/article/view/10118

23. Coelho FPS, Silva AM, Maniçoba RF. Aplicação das ferramentas da qualidade: estudo de caso em pequena empresa de pintura. Rev Fatec Zona Sul [Internet]. 2016 [cited 2021 Apr 22];3(1):31-45. Available from: http://www.revistarefas.com.br/index.php/RevFATECZS/article/view/70

24. Romero $\mathrm{DE}$, Cunha AB. Quality of socioeconomic and demographic data in relation to infant mortality in the Brazilian Mortality Information System (1996/2001). Cad Saúde Pública. 2006;22(3):673-84. https://doi.org/10.1590/S0102-311X2006000300022

25. Oliveira NB, Peres HHC. Quality of the documentation of the Nursing process in clinical decision support system. Rev Latino-Am Enfermagem. 2021;29:e3426-e3426. https://doi.org/10.1590/1518-8345.4510.3426

26. Barra DCC, Gapski GB, Paese F, Dal Sasso GTM, Sousa PAF, Alvarez AG, et al. Validation of nursing diagnosis for nursing consultation on home visit to adults. Rev Bras Enferm. 2021;74(2):e20200115. https://doi.org/10.1590/0034-7167-2020-0115

27. Gryschek LMS, Fracoli LA, Padoveze MC, Caballero SPO, Vilas Boas MAG. Critical analysis of the potential for the use of Nursing nomenclatures in primary health care. Enferm Foco. 2019;20(7):50-56. https://doi.org/10.21675/2357-707X.2019.v10.n7.2471

28. Dantas SGMR, Silva ALA, Souza ÂC. (2019). O Gerente de Unidade de Saúde da Família: reflexão teórica sobre o uso da CIPESC. Enferm Foco. 2019;10(6):188-192. https://doi.org/10.21675/2357-707X.2019.v10.n6.2389

29. Andrade CRB, Diógenes CC, Macêdo SM, Andrade ASS, Villa TCS, Pinto ESG. Planning and monitoring actions for tuberculosis control in Primary Health Care. Rev APS. 2017;40(4). https://doi.org/10.34019/1809-8363.2017.v20.15865

30. Vale DL, Freire VECS, Pereira LTB. Nursing consultation in people with tuberculosis: proposal of An instrument. Ciênc Cuid Saúde. 2020;19:e50102. https://doi.org/10.4025/cienccuidsaude.v19i0.50102

31. Wysocki AD, Ponce MAZ, Brunello MEF, Beraldo AA, Vendramini SHF, Scatena LM, Villa TCS. Primary Health Care and tuberculosis: services evaluation. Rev Bras Epidemiol. 2017;20:161-175. https://doi.org/10.1590/1980-5497201700010014

32. Barreto JDJS, Coelho MP, Lacerda LCX, Fiorin BH, Mocelin HJS, Freitas PDSS. Nursing records and the challenges of their implementation in the assistance practice. Rev Min Enferm. 2019;23:e-1234. https://doi.org/10.5935/1415-2762.20190082

33. Chotolli MR, Cucolo DF, Perroca MG. Assessment of the product of nursing care in specialized hospitals. Rev Bras Enferm. 2018;71(Suppl 6):2675-81. https://doi.org/10.1590/0034-7167-2017-0354 